\title{
Isolation, identification, and serotyping of Avibacterium paragallinarum from quails in Indonesia with typical infectious coryza disease symptoms
}

\author{
Agnesia Endang Tri Hastuti Wahyuni ${ }^{1}$, Charles Rangga Tabbu ${ }^{2}$, Sidna Artanto ${ }^{1}$, Dwi Cahyo Budi Setiawan ${ }^{3}$ and \\ Sadung Itha Rajaguguk ${ }^{4}$
}

\begin{abstract}
1. Department of Microbiology, Faculty of Veterinary Medicine, University of Gadjah Mada, Yogyakarta, Indonesia; 2. Department of Pathology, Faculty of Veterinary Medicine, University of Gadjah Mada, Yogyakarta, Indonesia; 3. Department of Pharmacology, Faculty of Veterinary Medicine, University of Gadjah Mada, Yogyakarta, Indonesia; 4. Department of Microbiology, Faculty of Veterinary Medicine, University of Gadjah Mada, Yogyakarta, Indonesia. Corresponding author: Agnesia Endang Tri Hastuti Wahyuni, e-mail: wahyuni_aeth@yahoo.com/wahyuni_aeth@ugm.ac.id

Co-authors: CRT: cranggatabbu@gmail.com, SA: adasidna@yahoo.com, DCBS: dwicahyobs@ugm.ac.id, SIR: sadung050493@gmail.com
\end{abstract}

Received: 08-12-2017, Accepted: 26-03-2018, Published online: 23-04-2018

doi: 10.14202/vetworld.2018.519-524 How to cite this article: Wahyuni AETH, Tabbu CR, Artanto S, Setiawan DCB, Rajaguguk SI (2018) Isolation, identification, and serotyping of Avibacterium paragallinarum from quails in Indonesia with typical infectious coryza disease symptoms, Veterinary World, 11(4): 519-524.

\begin{abstract}
Background and Aim: Infectious coryza (IC) or snot is an infectious upper respiratory disease affecting chickens and birds, including quails, and it is caused by Avibacterium paragallinarum. The symptoms of IC are facial swelling, malodorous nasal discharge, and lacrimation. This study aimed to isolate, identify, and serotype the A. paragallinarum of snot in quails and to determine the sensitivity and resistance to several antibiotics.

Materials and Methods: Nine quails from Yogyakarta, Indonesia with typical snot disease symptoms were used in this study. The nasal swab was obtained and directly streaked onto a chocolate agar plate and blood agar plate (BAP), then incubated in $5 \% \mathrm{CO}_{2}$ at $37^{\circ} \mathrm{C}$ for $24-48 \mathrm{~h}$. Staphylococcus spp. was cross-streaked onto the BAP to show the satellite growth. The observation of the morphology of the suspected colony, Gram staining, and biochemical tests (catalase test, oxidase test, urease test, peptone test, and carbohydrate fermentation such as maltose, mannitol, lactose, and sorbitol) are done to identify the species of bacteria. This research also detects the serovar of $A$. paragallinarum using hemagglutination inhibition test. The antibiotic sensitivity tests were also performed using several antibiotics against five A. paragallinarum isolates that were cultured on Mueller-Hinton Agar and added with antibiotic discs, then incubated in $5 \% \mathrm{CO}_{2}$ at $37^{\circ} \mathrm{C}$ for 24-48 h.
\end{abstract}

Results: Five isolates out of nine suspected isolates (55.5\%) were A. paragallinarum. The growth of isolates from quails did not depend on the nicotinamide adenine dinucleotide (NAD) (NAD-independent). Sensitivity test was done using the five identified A. paragallinarum isolates, results showed that they were $100 \%$ sensitive to amoxicillin (AMC) and ampicillin (AMP); 100\% resistant toward amikacin (AK), erythromycin (E), gentamycin (CN), and tetracycline (TE); 80\% resistant toward kanamycin (K) and trimethoprim (W); 60\% resistant toward chloramphenicol (C); and 20\% toward enrofloxacin (ENR). The antibiotics that have an intermediate sensitivity (in between sensitive and resistant) were ENR and K, $80 \%$ and $20 \%$, respectively. Three out of five A. paragallinarum isolates were identified as serovar B of A. paragallinarum using HI test.

Conclusion: Five out of nine isolates (55.5\%) from quails with typical IC disease symptoms identified as A. paragallinarum and sensitive toward AMC and AMP. Three out of five A. paragallinarum isolates were identified as serovar B.

Keywords: antibiotic sensitivity test, Avibacterium paragallinarum, infectious coryza, nicotinamide adenine dinucleotide-independent.

\section{Introduction}

Infectious coryza (IC) or snot is an infectious upper respiratory disease affecting poultry [1-3]. This disease is caused by Avibacterium paragallinarum, which was previously known as Haemophilus paragallinarum

Copyright: Wahyuni, et al. Open Access. This article is distributed under the terms of the Creative Commons Attribution 4.0 International License (http://creativecommons.org/licenses/ by/4.0/), which permits unrestricted use, distribution, and reproduction in any medium, provided you give appropriate credit to the original author(s) and the source, provide a link to the Creative Commons license, and indicate if changes were made. The Creative Commons Public Domain Dedication waiver (http:// creativecommons.org/publicdomain/zero/1.0/) applies to the data made available in this article, unless otherwise stated.
[4]. Some clinical signs that are commonly seen in IC are rhinitis, facial swelling or edema, anorexia, and retarded growth in young poultry [5-7]. The disease is very important in the chicken farm industry in developed and developing countries, including Indonesia [8]. The large economic losses due to IC such as increased number of culling, decreased egg production (10-80\%), decreased body weight, stunting growth, and some mortality (2-10\%) [4]. This disease can be found worldwide, especially in tropical countries. The diagnosis can be based on a history of rapid disease spread, clinical symptoms, and pathological changes caused by snot. Whereas, the definitive diagnosis of 
this disease can be made by isolating and identifying the causative bacteria in the acute stage of the disease and isolated directly using nasal swab from infraorbital sinus [9-11]. Advance molecular techniques such as HPG2-polymerase chain reaction (PCR), enterobacterial repetitive intergenic consensus-PCR, and $16 \mathrm{~s}$ rRNA sequencing can also be used for rapid and accurate identification of bacterium [12-14]. There are three major recognized A. paragallinarum serovars, which are serovar A, B, and C. Limited reports regarding the serovars of $A$. paragallinarum in Indonesia are available. This research was done to detect the serovar of $A$. paragallinarum in quail using hemagglutination inhibition (HI) test. It has been found that all three serovars of $A$. paragallinarum show variation in the virulence [15].

Snot commonly reported in the layers and broilers, compared to the quails [16]. The quails are susceptible to $A$. paragallinarum infection, but the isolation and characterization of this bacterium were rarely performed. In Indonesia, the snot reports in quails have been increasing in the past few years [17]. Many antibiotics have been used to treat snot, but many of them could only lower the severity of the disease without actually curing the disease completely. If the treatment was repeated, it would lead to resistance to certain antibiotics [11]. Therefore, the sensitivity tests of A. paragallinarum toward antibiotics are important to determine appropriate treatment regime for this disease.

This study aimed to isolate and identify A. paragallinarum in quails that showed typical symptoms of snot and to determine the sensitivity and resistance toward several antibiotics.

\section{Materials and Methods}

\section{Ethical approval}

No ethical clearance was needed for this research since the samples were obtained as per standard sample collections procedure without any harm to animals. Nasal swab samples were obtained from live animals without anesthetic treatment.

\section{Sample collection}

The samples were collected from nine quails with typical facial edema and discharges from nasal and infraorbital sinuses. The quails were from quail farm in Yogyakarta, Indonesia. The study was done in Microbiology Laboratory, Faculty of Veterinary Medicine, University of Gadjah Mada.

\section{Isolates and culture conditions}

There were nine quails showing typical clinical signs of IC. The samples collected were from nasal sinus discharge and infraorbital sinuses. The initial inoculation was performed onto chocolate agar plate (CAP) because this medium supplies $\mathrm{V}$ factor which is necessary for A. paragallinarum growth and then incubated in the 5\% $\mathrm{CO}_{2}$ incubator at $37^{\circ} \mathrm{C}$ for $24-48 \mathrm{~h}$. CAP medium can produce more $A$. paragallinarum colonies [18].
The suspected colony of $A$. paragallinarum was then cultured onto the blood agar plate (BAP), added with feeder bacteria, Staphylococcus sp. This was done by streaking inoculation loop perpendicular to the A. paragallinarum streaks (cross-streak) [19]. Afterward, the plates were incubated in the $5 \% \mathrm{CO}_{2}$ incubator at $37^{\circ} \mathrm{C}$ for $24-48 \mathrm{~h}[20]$. The colony with satellite growth was then stained using Gram staining method, tested for catalase test, oxidase test, motility test, urease test, and carbohydrate fermentation test $[5,21,22]$.

\section{Serotyping}

Three isolates were serotyped according to the Kume's scheme. The Kume serotyping was performed using antisera [23]. Antisera for HI test were provided by SHS International ${ }^{\circledR}$, which are serotype A (221 strain) and serotype B (Spross strain) from Aburahi Lab, Japan; while serotype C (Modesto strain) is from Animal Research Institute, Australia. Serotype C (Modesto strain) is from Animal Research Institute, Australia.

\section{Preparation of antigens for serotyping tests}

A. paragallinarum strains were microaerophilically grown in brain-heart infusion broth, supplemented with nicotinamide adenine dinucleotide (NAD) as supporting growth factor. After incubation, the broth was centrifuged twice at $3000 \times g$ for $15 \mathrm{~min}$ at $4^{\circ} \mathrm{C}$. The supernatant is removed, and phosphate-buffered saline (PBS) is homogenized with sediment before it is sonicated for $3 \mathrm{~min}$. The sonicated sediment is then added with the adequate amount of $\mathrm{NaCl} 0.15 \mathrm{M}$ so that the cloudiness of the solution matches with the turbidity of $0.5 \mathrm{McF}$ arland standard solutions [24]. The pellet was then resuspended in $4 \mathrm{ml}$ of PBS with thimerosal $(100 \mathrm{mg} / \mathrm{ml})$ and kept at $4^{\circ} \mathrm{C}$ until usage.

\section{Preparation of chicken erythrocytes}

Glutaraldehyde-fixed erythrocyte (GA-fixed RBC) suspension (30\%) in distilled water added with $100 \mathrm{mg} / \mathrm{ml}$ of thimerosal was prepared and kept in the dark at $4{ }^{\circ} \mathrm{C}$. When needed, this solution was diluted $1: 30$ in a working buffer consist of PBS ( $\mathrm{pH} 7.2)$ with $0.1 \%$ of bovine serum albumin and $0.001 \%$ of gelatin.

\section{Hemagglutination (HA) tests}

The HA titers of the antigens were determined with $40 \mu \mathrm{l}$ of reagent in a microdilution method. Doubling dilutions of antigen were made with working buffer. GA-fixed RBC ( $1 \%$ in working buffer) was added to each well, and the plates were incubated for $1 \mathrm{~h}$ at room temperature until the $\mathrm{RBC}$ control forms a pinpoint shape. The concentration of antigens is adjusted as a result of 4 HA unit is achieved.

\section{HI test}

Forty-microliter $(40 \mu 1)$ of doubling dilutions of antisera at 1:20-1:1.280 were prepared in working buffer. An equal amount of 4 HA unit antigen followed by $40 \mu 1$ of $1 \%$ GA-fixed RBC was added to each well. 
Plates were read after $1 \mathrm{~h}$ at room temperature. The HI titer was the most diluted antiserum that inhibits HA. The hemagglutinin serovar of each isolate was assigned according to the highest HI titer.

\section{Antimicrobial sensitivity test}

The antimicrobial sensitivity test was performed using Chukiatsiri et al. [25] method with some modifications. Isolates that have been identified as A. paragallinarum were tested against most commonly used antibiotic disc. A. paragallinarum cultured into the $\mathrm{TM} / \mathrm{SN}$ broth and incubated in the $5 \% \mathrm{CO}_{2}$ incubator at $37^{\circ} \mathrm{C}$ for $24-48 \mathrm{~h}$. The bacteria suspension was made equivalent to $0.5 \mathrm{McF}$ arland turbidity standard and then spread onto Mueller-Hilton Agar (MHA oxoid $^{\mathrm{TM}}$ ) medium with sterile swab. Antibiotic disc amoxicillin (AMC), ampicillin (AMP), chloramphenicol (C), trimethoprim (W), amikacin (AK), erythromycin (E), gentamycin (CN), tetracycline (TE), kanamycin (K), and enrofloxacin (ENR) were placed on the agar surface. The medium was incubated in the $5 \% \mathrm{CO}_{2}$ incubator at $37^{\circ} \mathrm{C}$. The zone of inhibition was observed after 24-48 $\mathrm{h}$ and the diameter of inhibition zone was measured and recorded in millimeters. The susceptibility category (sensitive, intermediate, or resistant) was determined by comparing the zone of antibiotic with the zone diameter breakpoint, as recommended by CLSI [26].

\section{Results}

The observation of the nine quails that were suspected IC disease showed that all of them had facial edema and produced malodorous mucopurulent nasal discharge. From the samples, five of them $(55.5 \%)$ were $A$. paragallinarum. The data of the quails that showed typical clinical signs of snot and their colony morphology can be seen in Table-1. The addition of Staphylococcus spp. onto BAP medium showed that $A$. paragallinarum isolates from quails were NADindependent (Figure-1). Five isolates (Q3, Q4, Q5, Q7, and Q9) showed biochemical characteristics of A. paragallinarum, i.e., negative catalase, negative oxidase, negative urease, negative in indole test, and capable to fermenting carbohydrate (Table-2).
The 4 HA unit antigen was used to perform HI test immediately as further prolongation may cause an alteration in the concentration of antigen. Due to antisera limitation, $\mathrm{HI}$ test is only done on three isolates, i.e., Q5, Q7, and Q9 isolate. The result showed that the three isolates were serovar B strain.

The sensitivity test of $A$. paragallinarum shows different result toward all the antibiotics (Table-3). The sensitivity level toward AMC and AMP was $100 \%$, toward $\mathrm{C}$ and $\mathrm{W}$ was $20 \%$, whereas these bacteria were $100 \%$ resistant toward $\mathrm{AK}, \mathrm{E}, \mathrm{CN}$, and TE; $80 \%$ toward $\mathrm{K}$ and $\mathrm{W} ; 60 \%$ toward $\mathrm{C}$; and $20 \%$ toward ENR. The antibiotics that have an intermediate sensitivity (in between sensitive and resistant) were ENR and $\mathrm{K}, 80 \%$ and $20 \%$, respectively.

\section{Discussion}

The clinical signs showed in the chicken suspected IC are facial swelling or facial edema, discharge from nasal sinuses, conjunctivitis, and decreased egg production [27-29]. Whereas infected quails that show typical signs would also produce foul smell in chronic infection [11]. The quails are susceptible to this disease in all ages [22].

There were two colony morphologies on CAP from the first culture of samples (Table-1). The A. paragallinarum colony on CAP is circular, transparent,

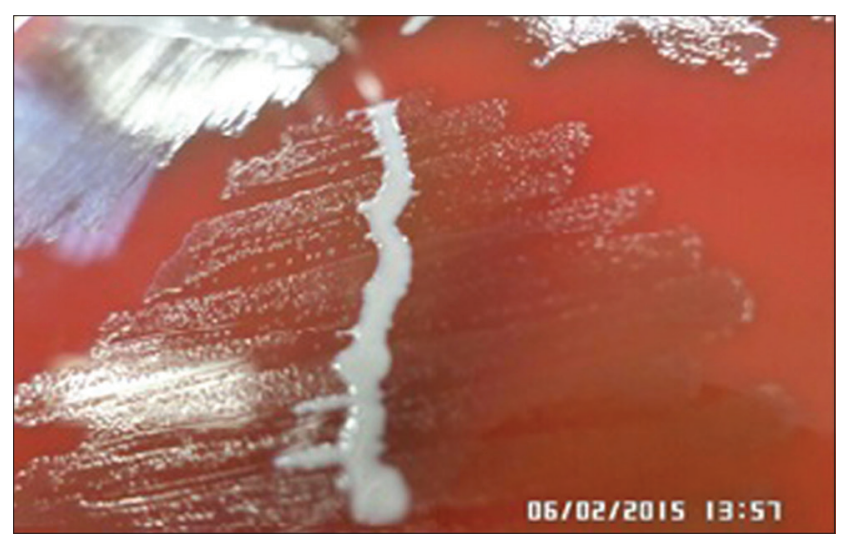

Figure-1: Colony morphology of Avibacterium paragallinarum $(\mathrm{A})$ in BAP added with Staphylococcus spp (B) culture.

Table-1: Quail's data showing typical snot clinical signs with their colony morphology on CAP.

\begin{tabular}{|c|c|c|c|c|c|}
\hline \multirow{3}{*}{$\begin{array}{l}\text { Sample } \\
\text { code }\end{array}$} & \multicolumn{2}{|r|}{ Clinical signs } & \multicolumn{3}{|c|}{ Suspected colony morphology } \\
\hline & \multirow[t]{2}{*}{ Facial edema } & \multirow[t]{2}{*}{ Malodorous nasal discharge } & \multicolumn{2}{|c|}{ Color } & \multirow{2}{*}{$\begin{array}{c}\text { Shape } \\
\text { Circular }\end{array}$} \\
\hline & & & Smooth, transparent & White, compact & \\
\hline Q1 & + & + & + & + & + \\
\hline $\mathrm{Q} 2$ & + & + & + & + & + \\
\hline Q3 & + & + & + & + & + \\
\hline Q4 & + & + & + & + & + \\
\hline Q5 & + & + & + & + & + \\
\hline Q6 & + & + & + & + & + \\
\hline Q7 & + & + & + & + & + \\
\hline Q8 & + & + & + & + & + \\
\hline Q9 & + & + & + & + & + \\
\hline
\end{tabular}

$\mathrm{CAP}=$ Chocolate agar plate 
Table-2: Biochemical test results of suspected colonies isolated from quails showing snot symptoms.

\begin{tabular}{|c|c|c|c|c|c|c|c|c|c|c|}
\hline Sample code & Shape & $\mathbf{K}$ & $\mathbf{0}$ & $\mathbf{U}$ & $\mathbf{I}$ & $\mathbf{M t}$ & $\mathbf{M}$ & Ma & $\mathbf{L}$ & $\mathbf{S}$ \\
\hline Q1 & Coccobacillus & + & + & + & + & - & + & + & - & + \\
\hline Q2 & Coccobacillus & + & - & + & + & + & - & - & - & - \\
\hline Q3+ & Coccobacillus & - & - & - & - & - & + & + & $+*$ & + \\
\hline Q4+ & Coccobacillus & - & - & - & - & - & + & + & + & + \\
\hline Q5+ & Coccobacillus & - & - & - & - & - & + & + & + & + \\
\hline Q6 & Coccobacillus & + & - & - & - & + & - & - & + & - \\
\hline Q7+ & Coccobacillus & - & - & - & - & - & + & + & + & + \\
\hline Q8 & Coccobacillus & + & - & - & - & + & - & - & + & - \\
\hline Q9+ & Coccobacillus & - & - & - & - & - & + & + & $+^{*}$ & + \\
\hline
\end{tabular}

$\mathrm{K}=$ Catalase, $\mathrm{I}=$ Indole, $\mathrm{Ma}=$ Maltose, $\mathrm{O}=$ Oxidase, $\mathrm{Mt}=$ Motility, $\mathrm{L}=$ Lactose, $\mathrm{U}=$ Urease, $\mathrm{M}=\mathrm{Mannitol}$, $\mathrm{S}=\mathrm{Sorbitol}$,

${ }^{+}$A. paragallinarum, *Low fermentation, $A$. paragallinarum=Avibacterium paragallinarum

Table-3: Result of sensitivity test of $A$. paragallinarum isolated from quails toward 10 antibiotics.

\begin{tabular}{|c|c|c|c|c|c|c|c|c|c|c|}
\hline \multirow{2}{*}{$\begin{array}{l}\text { Isolate } \\
\text { code }\end{array}$} & \multicolumn{10}{|c|}{ Inhibition zone (mm) } \\
\hline & AK & AMC & ENR & AMP & C & $\mathbf{E}$ & $\mathbf{C N}$ & $\mathbf{K}$ & TE & $\mathbf{w}$ \\
\hline Q3 & $0(R)$ & $32(S)$ & $22(\mathrm{I})$ & $30(S)$ & $10(\mathrm{R})$ & $0(R)$ & $9(\mathrm{R})$ & $0(\mathrm{R})$ & $0(R)$ & $0(\mathrm{R})$ \\
\hline Q4 & $10(\mathrm{R})$ & $31(\mathrm{~S})$ & $11(\mathrm{R})$ & $27(S)$ & $24(S)$ & $10(\mathrm{R})$ & $0(R)$ & $0(\mathrm{R})$ & $0(\mathrm{R})$ & $0(R)$ \\
\hline Q5 & $10(\mathrm{R})$ & $30(S)$ & $18(\mathrm{I})$ & $28(S)$ & $10(\mathrm{R})$ & $10(\mathrm{R})$ & $10(\mathrm{R})$ & $0(\mathrm{R})$ & $0(R)$ & $10(\mathrm{R})$ \\
\hline Q7 & $10(\mathrm{R})$ & $18(S)$ & $22(\mathrm{I})$ & $27(S)$ & $16(\mathrm{I})$ & $10(\mathrm{R})$ & $11(\mathrm{R})$ & $15(\mathrm{I})$ & $9(\mathrm{R})$ & $28(S)$ \\
\hline Q9 & $10(\mathrm{R})$ & $30(S)$ & $22(\mathrm{I})$ & $24(S)$ & $12(\mathrm{R})$ & $10(\mathrm{R})$ & $10(\mathrm{R})$ & $0(\mathrm{R})$ & $0(\mathrm{R})$ & $10(R)$ \\
\hline
\end{tabular}

$\mathrm{R}=$ Resistant, $\mathrm{I}=$ Intermediate, $\mathrm{S}=$ Sensitive, $A$. paragallinarum=Avibacterium paragallinarum, AK=Amikacin, $\mathrm{AMC}=$ Amoxicillin, $\mathrm{ENR}=$ Enrofloxacin, $\mathrm{AMP}=$ Ampicillin, $\mathrm{C}=$ Chloramphenicol, $\mathrm{E}=$ Erythromycin, $\mathrm{CN}=\mathrm{Gentamycin}$, $\mathrm{K}=$ kanamycin, $\mathrm{TE}=$ Tetracycline, $\mathrm{W}=$ Trimethoprim

and smooth dewdrops (Figure-2).. This bacterium had relatively slow growth and could be detected after being incubated for 36-48 h [13]. Besides A. paragallinarum, Staphylococcus sp. can also grow on this medium and could be well observed with white circular morphology. Gram stain of A. paragallinarum showed that bacteria were coccobacilli morphology and red color (Gram-negative). The result obtained matches with the study reported by Akhter et al. [18] and Priya et al. [30]. Colonies with morphological characteristics leading to $A$. paragallinarum colonies were recultured until got pure colony.

The suspected colony was isolated to BAP medium and added with Staphyococcus spp. as bacterial feeder $[31,32]$. The $A$. paragallinarum that needs $\mathrm{V}$ factor would grow alongside the bacteria feeder and form satellite colony $[3,4,33,34]$, while some $A$. paragallinarum species could grow even without $\mathrm{V}$ factor. The addition of Staphylococcus sp. onto BAP medium in this study showed that A. paragallinarum isolates from quails were NAD-independent. The colony had bigger size (1-2 mm) compared to NAD-dependent $A$. paragallinarum isolates $(0.3 \mathrm{~mm})$ and did not show any satellite colony [25]. The NAD-independent isolates had lower virulence level compared to NADdependent isolates, but the differences have not yet been explained [31].

Five isolates (Q3, Q4, Q5, Q7, and Q9) showed biochemical characteristics of $A$. paragallinarum, i.e., negative catalase, negative oxidase, negative urease, negative in indole test, and capable to fermenting all carbohydrate that used, which are also reported by Blackall and Soriano [19]. Two of five (Q3 and

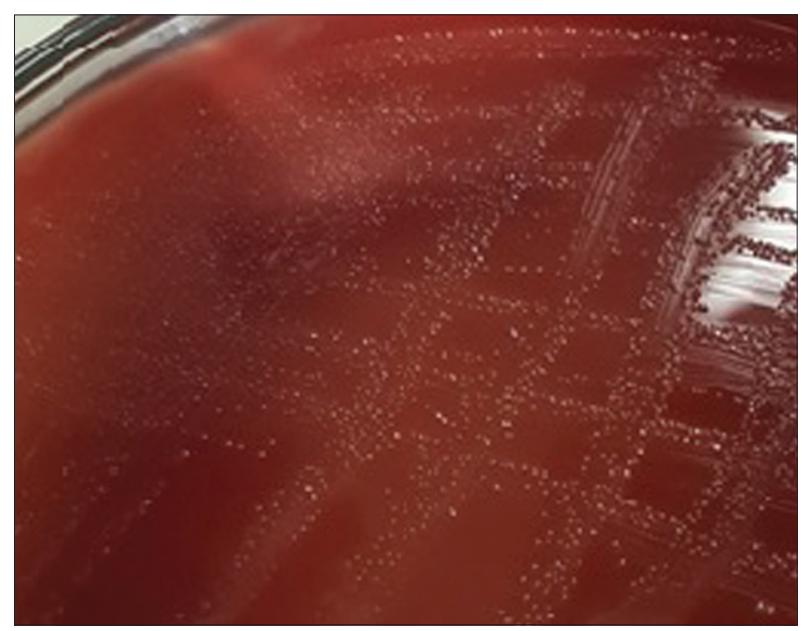

Figure-2: Morphology colony of Avibacterium paragallinarum in CAP

Q9) isolates showed low fermentation of lactose. The same results were reported by Akhter et al. [5], that ability of fermenting lactose is variable. Four other identified isolates showed differences in the ability of fermenting carbohydrates. The other biochemical tests also do not confirm that the four isolates are A. paragallinarum.

Hemagglutinin (HA) proteins have an important role in the pathogenesis and immunopathogenesis of A. paragallinarum [35]. The HA test is necessary before HI test as 4 HA unit of antigen concentration is required for $\mathrm{HI}$ test and also to confirm the ability of bacteria to agglutinate erythrocytes [23]. The 4 HA unit antigen was used to perform HI test immediately as further prolongation may cause an alteration in the concentration of antigen. HI test 
is normally done to detect the minimum antibody titer needed to inhibit the action of HA. According to Blackall and Soriano [19], two separate serotyping schemes were used for detection of A. paragallinarum on the serological level, Page scheme (1962) and Kume scheme (1983). The HA-HI test is chosen based on the availability of antisera. Due to antisera limitations, HI test was only done on three isolates, i.e., Q5, Q7, and Q9. The result showed that three isolates were serovar B.

Sensitivity of $A$. paragallinarum to AMC and AMP was $100 \%$, to $\mathrm{C}$ and $\mathrm{W}$ was $20 \%$, whereas resistance of A paragallinarum to $\mathrm{AK}, \mathrm{E}, \mathrm{CN}$, and $\mathrm{TE}$ was $100 \%$; $\mathrm{K}$ and $\mathrm{W}$ was $80 \%$; $\mathrm{C}$ was $60 \%$; and $\mathrm{ENR}$ was $20 \%$. Antibiotics that had intermediate sensitivity were ENR and K, $80 \%$ and $20 \%$ respectively. The resistance level toward erythromycin was more than $75 \%$ similar to other studies $[25,36]$, whereas the high level of resistance toward tetracycline also reported by Thenmozi and Malmarungan [22] that occurred up to $70 \%$. According to Rajurkar et al. [37], six $A$. paragallinarum in India used in their studies were all resistant to tetracycline. From anamnesis obtained, it was clear that the quails already obtained antibiotic treatment of enrofloxacin and neomycin. The resistance level toward tetracycline occurred in Indonesia because tetracycline is commonly used in the field to combat the snot disease, besides the erythromycin and sulfonamide [38].

\section{Conclusion}

Five out of nine isolates $(55.5 \%)$ from quails with typical IC disease symptoms identified as A. paragallinarum and sensitive to AMC and AMP. Three out of five $A$. paragallinarum isolates were identified as serovar B. Isolation, identification, and serotyping of $A$. paragallinarum in this study are important to provide solutions to the control coryza disease. From reports of field cases in Indonesia, commercial vaccine has not been able to cover the incidence of IC. Serotyping of $A$. paragallinarum is important to identify the serovars that commonly cause coryza infection in quail, therefore, serovar-specific vaccination to prevent occurrence of coryza in quail can be carried out more effectively. While antibiotic sensitivity test provides useful suggestion for appropriate treatment that is effective and efficient against the bacterial infection. Molecular characterization and serotyping of $A$. paragallinarum with multiplex PCR will be researched on the next project.

\section{Authors' Contributions}

AETHW contributed in isolation and identification process of $A$. paragallinarum, serotyping analysis. CRT contributed in the detection of clinical symptoms of snot in the farm. SA contributed in the serotyping test. DCBS contributed in antibiotic sensitivity test. SIR contributed in collecting samples. All authors read and approved the final manuscript.

\section{Acknowledgments}

We would like to thank the Directorate of Research and Community Service, General Directorate of Higher Education, Education, and Cultural Ministry that kindly granted us the Higher Education Research Fund 2015 .

\section{Computing Interests}

The authors declare that they have no competing interests.

\section{References}

1. Blackall, P.J. and Hinz, K. (2008) Infectious Coryza and Related Disease. In: Pattison, M., Mc Mullin, P.F., Bradbury, J.M. and Alexander, D.J., editors. Poultry Disease. $6^{\text {th }}$ ed. WB Saunders. Company, London. p155-159.

2. Garcia, A.J., Angulo, E., Blackall, P.J. and Ortiz, A.M. (2004) The presence of nicotinamide adenine dinecleotide-independent Haemophilus paragallinarum in Mexico. Avian Dis., 48: 425-429.

3. Quinn, P.J., Markey, B.K., Carter, M.E., Donelly, W.J.C. and Leonard, F.C. (2004) Veterinary Microbiolgy and Microbial Disease, Blackwell Publishing, UK. p273-277.

4. Blackall, P.J., Christensen, H., Beckenham, T., Blackall, L.L. and Bisgaard, M. (2005) Reclassification of Pasteurella gallinarum, Haemophilus paragallinaarum, Pasteurella avium and Pasteurella volantium as Avibacterium gallinarum gen. nov., Avibacterium paragallinarum comb. nov., Avibacterium avium comb. nov. and Avibacterium volantium comb. nov. Int. J. Syst. Evol. Microbiol., 55: 353-362.

5. Akhter, S., Ali, M., Das, P.M. and Hossain, M.M. (2013) Isolation and identification of Avibacterium paragallinarum, the causal agent of infectious coryza (IC) from layer chickens in Bangladesh. J. Bangladesh Agric. Univ., 11: 87-96.

6. Durairajan, R., Sharma, M. and Murugan, M.S. (2013) Detection of Avibacterium paragallinarum in commercial poultry and their antibiogram. Tamil Nadu J. Vet. Anim. Sci., 9: 332-337.

7. Patil, V.V., Mishra, D.N. and Mane, D.V. (2016) Isolation, characterization and serological study of Avibacterium paragallinarum field isolates from Indian poultry. J. Anim. Poult. Sci., 5: 13-20.

8. Ariyanti, T. andSupar. (2007) Pengendalian coryza infeksius pada ayam. Wartazoa, 17: 185-191.

9. Vegad, J.L. and Katiyar, A.K. (2008) A Textbook of Veterinary Special Pathology. International Book Distributing Co., New Delhi. p304-306.

10. Shane, S.M. (2005) Coryza: Handbook on Poultry Disease. American Soybean Association, Singapore. p99-100.

11. Tabbu, C.R. (2000) Penyakit Ayam dan Penanggulangannya. Vol. 1. Kanisius, Yogyakarta. p14-20.

12. El-Sawah, A., Soliman, Y.A. and Shafey, S.M. (2014) Molecular characterization of Avibacterium paragallinarum strain used in evaluation of coryza vaccine in Egypt. J. Am. Sci., 8: 253-263.

13. Muhammad, T.M.N., dan Sreedevi, B. (2015) Detection of Avibacterium paragallinarum by polimerase chain reaction from outbreaks of infectious coryza of poultry in Andhra Pradesh. Vet. World, 8: 103-108.

14. Patil, V.V., Mishra, D. and Mane, D.V. (2017) 16S ribosomal RNA sequencing and molecular serotyping of Avibacterium paragallinarum isolated from Indian field conditions. Vet. World, 10: 1004-1007.

15. Patil, V., Mishra, D. and Mane, D. (2017) Virulence pattern of Avibacterium paragallinarum isolates studied from Indian field condition. Int. J. Livestock Res., 7: 201-207.

16. Blackall, P.J. and Yamamoto, R. (1989) Infectious Coryza. In: Isolation and Identification of Avian Pathogens. $3^{\text {th }}$ ed. 
American Association of Avian Pathogens, Inc., Iowa. p27-31.

17. Quinn, P.J., Markey, B.K., Leonard, F.C., Fitzpatrick, E.S., Fanning, S. and Hartigan, P.J. (2011) Veterinary Microbiology and Microbial Disease. Wiley-Blackwell, Iowa. p451-460.

18. Akhter, S., Saha, S., Khan, K.A., Amin, M.M. and Haque, M.E. (2014) Isolation and identification of Avibacterium paragallinarum from layer chickens in Gazipur, Bangladesh. Microbes Health, 3: 9-11.

19. Blackall, P.J. and Soriano, E.V. (2008) Infectious coryza and related bacterial. In: Disease of Poultry. $12^{\text {th }}$ ed. Blackwell Publishing, Oxford. p789-803.

20. Markey, B.K., Leonard, F.C., Archambault, M. (2013) Clinical Veterinary Microbiology. Mosby Elseiver, Edinburgh. p307-314.

21. Leboffe, M.J. and Pierce, B.E. (2011) A Photographic for The Microbiology Laboratory. Atlas Edition. Morton Publishing, US. p55, 71-73, 74-75, 82, 96-97.

22. Thenmozi, V. and Malmarungan, S. (2013) Isolation and Identification and Antibiogram Pattern of Avibacterium paragallinarum from Japanese Quails. Tamil Nadu J. Vet. Anim. Sci., 9: 253-258.

23. Eaves, L.E., Rogers, D.G. and Blackall, P.J. (1989) Comparison of hemagglutinin and agglutinin schemes for the serological classification of Haemophilus paragallinarum and proposal of a new hemagglutinin serovar. $J$. Clin. Microbiol., 27: 1510-1513.

24. Sawata, A., Kume, K. and Nakase, Y. (1982) Hemagglutination of Haemophilus paragallinarum serotype 2 organisms: Occurrence and immunologic properties of hemagglutinin. Am. J. Vet. Res., 43: 1311-1319.

25. Chukiatsiri, K., Sasipreeyajan, J., Blackall, P.J., Yuwatanichsampan, S. and Chansiripornchai, N. (2012) Serovar identification, antimicrobial sensitivity and virulence of Avibacterium paragallinarum isolated from chickens in Thailand. Avian Dis., 56: 359-364.

26. CLSI (Clinical and Laboratory Standards Institute). (2008) Performance Standards for Antimicrobial Disk and Dilution Susceptibility Tests for Bacteria Isolated from Animals; Approved Standard, $3^{\text {rd }}$ Ed. M31-A3. CLSI, Wayne, PA.

27. Ali, M., Hossain, M.S., Akter, S., Khan, M.A.H.N.A. and dan Hossain, M.M. (2013) Pathogenesis of infectious coryza in chickens (Gallus gallus) by Avibacterium paragallinarum isolate of Bangladesh. Agriculturists, 11: 39-46.

28. Anjaneya, Singh, S.D., Dhama, K., Gowthaman, V. and Chawak, M.M. (2013) Pathogenicity study of field isolates of Avibacterium paragallinarum in experimentally infected birds. Indian J. Vet. Pathol., 37: 13-17.

29. Kaur, J., Sharma, N.S., Kuldip, G. and Amarjit, S. (2004) Epidemiological studies on IC in chickens in Northern India. Indian J. Anim. Sci., 74: 462-465.

30. Priya, P.M., Krishna, S.V., Dineskhumar, V. and Mini, M. (2012) Isolation and charaecterization of Avibacterium paragallinarum from ornamental birds in Thrissur, Kerala. Int. J. Life Sci., 1: 87-88.

31. Bragg, R.R. (2002). Virulence of south African isolates of Haemophillus paragallinarum. Part 2: Naturally occuring NAD-independent field isolates. Onderstepoort J. Vet. Res., 65: 171-175.

32. Blackall, P.J. and Reid, G.G. (1982) Pathogenicity of Australian isolates of Haemophilus paragallinarum and Haemophilus avium in chicken. Vet. Biol., 9: 77-82.

33. Blackall, P.J. (2008) Infectious coryza. In: A Laboratory Manual for the Isolation and Identification of Avian Pathogens. American Association of Avian Pathologists, Inc., Iowa. p22-26.

34. Badouei, M.A., Sadrzadeh, A., Azad, N., Blackall, P., Madadgar, O. and Charkhkar, S. (2014) Isolation and molecular identification of Avibacterium paragallinarum in suspected cases of infectious coryza. Turk. J. Vet. Anim. Sci., 38: 46-49.

35. Wang, Y., Hsieh, M.K., Tan, D.Y., Shien, J.H., Ou, S.C., Chen, C.F. and Chang, P.C. (2014) The hemagglutinin of Avibacterium paragallinarum is a trimeric autotransporter adhesin that confers haemagglutination, cell adherence and biofilm formation activities. J. Vet. Microbiol., 174: 474-482.

36. Hsu, Y.M., Shieh, H.K., Chen, W.H., Sun, T.Y. and Shiang, J.H. (2007) Antimicrobial susceptibility, plasmid profiles and haemocin activities of Avibacterium paragallinarum strains. J. Vet. Microbiol., 124: 209-218.

37. Rajurkar, G., Roy, A. and Yadav, M.M. (2010) An overview on epidemiologic investigations of infectious coryza. Vet. World, 2: 401-403.

38. Poernomo, S., Sutarma, Raffie, M. and Blackall, P.J. (2000) Characterisation of isolates of Haemophilus paragallinarum from Indonesia. Aust. Vet. J., 78: 759-762.

$* * * * * * * *$ 